\title{
Forum
}

Members of the Association are invited to submit letters, typed and double-spaced, commenting on articles published in PMLA or on matters of general scholarly or critical interest. Footnotes are discouraged, and letters of more than one thousand words will not be considered. Decision to publish and the right to edit are reserved to the Editor, and the authors of the articles discussed will be invited to reply.

\section{Patterning in Beowulf, Continued}

\section{To the Editor:}

I enjoyed John D. Niles's article "Ring Composition and the Structure of Beowulf" (PMLA, 94 [1979], 924-35), not least because I have found passages in Old Icelandic sagas that might be added to his list of examples.

I do not, however, immediately understand the objections to the numerological analyses done by Hart and others that Niles sets forth in his third note. According to Niles, "the line numeration of Beowulf is a modern invention" (p. 933). Does Niles mean that because the Beowulf poet had no lineated copy of the text before him, he had no idea how many lines of poetry he had composed? If this is what Niles means, $I$ find his position an unreasonable one and an insufficient reason for rejecting Hart's work. What was to prevent the poet from keeping track of the number of lines-by means of chalk and slate, for example-if he had a reason to do so? The wish properly to complete the parts of a numerological pattern (whose proportions and 'factors had perhaps symbolic meaning) would be such a reason.

In Egils saga Skallagrimssonar we have an account of an oral poet's completing a prescribed pattern in the composition of Hofudlausn: the prescription is for a drápa tvítug, a twenty-stanza poem of praise with an upphaf (introduction), stef (middle section with refrains), and slamr (conclusion). The upphaf is two and a half stanzas long (twenty lines); the slamr is of equal length: if Egil had not kept count of the number of lines and stanzas he had composed, how could he have known when to start the slamr and how long to make it so that it would be symmetrical with the upphaf? Granted, a drápa tvitug's pattern is much less complicated than the one Hart proposes for Beowulf, but the principle - the filling in of a prescribed pattern that obliges the poet to keep track of how many lines he has composed at any given time-is the same.

The presence of lacunae does pose a problem to numerological analysis. A further problem, at least for me, is that analysts sometimes fail to draw any connection between the patterns they find and the meanings of the poems in which they find them. I would like to see the preplanned pattern working right along with a poem's diction and subject matter in the service of the poem's theme; otherwise, I find it unlikely that a poet would go to the trouble of making a numerological pattern at all. In "Schematic Form and Its Symbolism in The Phoenix" (Viator, 11 [1980], 95-121), Robert D. Stevick successfully applies numerological analysis to a poem that has no lacunae, and he goes on to link the symbolic meaning of the factors in the pattern with the meaning of the poem. Furthermore, he uses the numerological pattern to account for the awkwardness in lines $380-86$ of The Phoenix, a passage long considered by literary critics to be the unhappy result of the poet's inability to bridge the gap between the fable of the first part of the poem and the exegesis of the last part.

A few years ago, one might have attributed the turning up of a complex numerological pattern in an Old English poem to the working of the laws of coincidence. But as more works are found to contain such patterns, it seems to me that the role of coincidence must be viewed as inconsiderable. The patterns are there, and we must deal with them; the argument that a given poet had no way of knowing how many lines of poetry he had composed at a given time during the process of composition is not a sufficient reason for us to dismiss from consideration the work of Hart, Stevick, and others. The fourbeat alliterative line is not, after all, a typographical convention: it is a group of words with four stresses, alliteration, a hofüstafr, and two stuठlar, a pattern recognized by the ear.

\section{T. C. S. LANGEN \\ Seattle, Washington}

\section{To the Editor:}

The confident claim of John D. Niles that Beowulf "as a whole has the solidity and grace of a well-planned piece of architecture" (p. 931) is a telling index of how far Beowulf scholarship has now come from the once canonical view that the poem is structurally deficient, even clumsy. Like many of the recent precursors he cites, Niles finds 


\section{Forum}

"patterns" of textual organization that suggest that the poet used quite sophisticated compositional techniques. Yet here, as with much "structural" analysis, a fundamental question remains unanswered: Are the patterns the poet's or the critic's? Specifically, did the Beowulf poet conceive the recurrence of certain themes as "balance" and "opposition" (with Tolkien), as "envelope" (with Bartlett and Hieatt), as "spiral" (with Nist), as "interlace" (with Leyerle), as "ring composition" (with Niles), as some combination of these (e.g., "ring composition ... as one special type of interlace design" [p. 933]), or as something else?

Evidence is emerging that may help answer such questions - the systematic properties of the poem's tectonic (or numerical) design. While citing two of my essays on this evidence (pp. 932-33, n. 3), Niles explicitly excludes from consideration aspects of my findings that would seem to be directly relevant to his thesis. For example, on page 929 (and in Diagram 6) he proposes a seven-member symmetrical pattern. As my 1972 essay showed, important features of the two symmetrical "interludes" in this pattern, the episodes about Finn and Ingeld, are marked not only by unique thematic and verbal collocations but also by arithmetically precise symmetrical placement within the 3,182-line text-in all, a conjunction of verbal, thematic, and numerical features that seems too harmonious in detail to have arisen without conscious calculation by the poet (cf. 1l. 1114-59a and 2024b-69a). Niles maintains, perhaps as a reason for disregarding the numerical features of this symmetry, that "the modern lineation of the poem seems rather problematical" ( $p$. 933). "Problematical" appears too strong a term, given the unanimous agreement of all recent editors on the line count 3,182 and the generations of meticulous editorial scholarship on which that agreement is based (for discussion of the concerns Niles mentions, see pp. 32 and 49-50 of my 1972 essay and Howlett's essay [also cited in n. 3], pp. 324-25). Yet clearly, traditional kinds of textual evidence, taken alone, have not succeeded in dispelling all doubt about the lineation. Here again the emerging numerical dimension offers new, independent means of proof. If the poet did, as I claim, create a number-based design in advance (computed on the total 3,182 and informed by precise arithmetic proportionality, especially that derived from the constant properties of simple geometric figures) and then composed the text into that abstract design, the numerical logic of the design itself should reveal whether the received line count is correct.

Because the documented existence of such an authorial design would also provide important new means of evaluating structural hypotheses like
Niles's, it seems especially relevant to underscore the reliability of the "modern lineation." Accordingly, the earlier evidence may be supplemented here by citing the rigorous numerical constraints underlying another of Niles's own patterns. Illustrating "the Beowulf poet's tendency toward stylization and patterning," Niles notes: "Three times the dragon attacks before Beowulf and his young kinsman Wiglaf cut him down (see 11. 2569, 2669-70, 2688)" (p. 927). To keep the proof succinct I merely outline a step-by-step procedure by which the poet could readily have constructed the (geometrically) proportional pattern I believe governs the placement of these three passages and invite readers to diagram for themselves the "design" produced by this (or some directly corollary) procedure.

Hypothesis: I (the poet) wish the recurrent features of the dragon fight to be unified by numerical proportionality that, where possible, will also harmonize reasonably with textual meaning. (This is an essential component of my-and my age'sliterary aesthetic.) The dragon is coiled ("gebogen," 1. 2569), which implies, let us say, circularity. I draw a circle. The attack is to be threefold ("oore siðe," 1. 2670, and "priddan siðe," 1. 2688), which suggests triangularity. I inscribe an equilateral triangle within the circle. I know from elementary geometry (one of the traditional mathematical artes of the early medieval curriculum; see Aldhelm's letters 1 and 5) that the ratio between the perimeter of an equilateral triangle and the radius of the circumscribed circle is $3 \sqrt{3}: 1$. Using $26 / 15$ as a convenient fractional approximation for the irrational $\sqrt{3}$ I calculate the constant ratio between triangle and radius to be $3(26 / 15)$ or $26 / 5$. This I establish as the controlling ratio for all three stages of the attack. Now for the specific derivation of the initial stage: I divide the predetermined line total 3,182 by $26 / 5$ and get 612 (rounded to the nearest integer); that is, if an equilateral triangle with perimeter totaling 3,182 is inscribed within a circle, the radius of the circle is about 612 . Next I subtract 612 from 3,182; the result is 2,570. Here, 612 lines from the end of the poem, I write: "Gewat ta byrnende gebogen scriðan, / to gescipe scyndan" (11. 2569-70a; emphasis added). To derive the final stage of the attack I apply the same procedure to the sum 2,570 (first-stage line number) thus: $2,570 \div$ $26 / 5=494$. That is, if the triangle totals 2,570 , the radius of the circumscribed circle is about 494 . From 3,182 I now subtract 494, yielding 2,688. Here, 494 lines from the end of the poem, I write: "pa wæs peodsceaða priddan siðe, / frecne fyrdraca fæhða gemyndig, / ræsde on ðone rofan" (11. 268890a; emphasis added). This makes the first and last 
attack stages positionally proportional (both, of course, by the triangle-circle constant that was utilized). To continue the proportionality to the yetto-be-positioned second attack stage I simply apply a corollary of the first-stage proportionality to the poem's line total: $3,182 \times 3,182 /(3,182+612)=$ 2,669. Here I write: "Æfter đam wordum wyrm yrre cwom, / atol inwitgæst oðre siðe" (11. 266970 ; emphasis added). By this procedure I have created a proportional design so unified that eight of the nine text intervals generated by the three passages are not only proportional among themselves, they also interrelate as any equilateral triangle to the radius of its circumcircle: $3,182 / 612=612 / 118$ $=2,669 / 513=513 / 99=99 / 19=2,570 / 494(=$ $26 / 5=$ approx. $3 \sqrt{3}$ ). (If 11. 2570,2669 , and 2688 are labeled as points $\mathrm{A}, \mathrm{B}$, and $\mathrm{C}$ respectively within the text as a 3,182-line continuum, the nine intervals they define are as follows: start to $A=2,570$; $\mathrm{A}$ to end $=612$; start to $\mathrm{B}=2,669 ; \mathrm{B}$ to end $=$ 513 ; start to $\mathrm{C}=2,688 ; \mathrm{C}$ to end $=494 ; \mathrm{A}$ to $\mathrm{B}=$ 99; $\mathrm{B}$ to $\mathrm{C}=19$; $\mathrm{A}$ to $\mathrm{C}=118$. Regarding the compositional procedure mapped here, compare the cognate geometrical techniques that R. L. S. BruceMitford reconstructed from compass pricks and other physical evidence in the Lindisfarne Gospels ["The Methods of Construction of the Insular Ornament," in Codex Lindisfarnensis, ed. T. J. Brown et al., 2 vols. (Oltun: Graf, 1960), Ir, 1:221-31].)

This remarkably precise proportionality would not hold if the preserved text lacked one line of the poet's original total. Thus, like the arithmetically precise symmetry of the Finn and Ingeld episodes, the proportional placement of one of the patterns Niles proposes once again helps confirm both the "pattern" and the preserved line count 3,182 as the poet's own.

\section{THOMAS ElWOOD HART \\ Syracuse University}

\section{Mr. Niles replies:}

It comes as no surprise to me to learn that the designer of the exquisite illuminations of the Lindisfarne Gospels used a compass to plan his work. I shall be more than surprised, however, if Hart can show that the Beowulf poet did likewise.

One basic rule of detective work is that you find what you are looking for. John Nist was looking for spirals in the design of Beowulf; he found them. John Leyerle was looking for interlace; he found it. I was looking for interlocking chiasmus and was equally successful. The point is that the poem yields good results if one approaches it with an eye to detecting thematic parallelism and contrast. Parallel structure, the reiteration of similar themes, the ar- rangement of narrative events into contrastive pairs -these seem to be basic features of the art of the Beowulf poet. It doesn't much matter what shape of diagram one uses to make this patterning clear. Grids, gyres, over-and-under weaves - all might help our conceptual understanding of what the poet has done. What matters is to see that the patterning is there, in the large design as well as on the level of the formulaic phrase.

Hart has been looking for precise numerical proportionality within the design of Beowulf, and he has found that too. Even more than other structural approaches, numerological studies are bound to be successful. Any literary work can be divided into proportional arithmetic units, and if one chooses these units well and exercises sufficient ingenuity, they can always be shown to be significant.

To my mind, the recalcitrant problem with numerical analyses of Beowulf is the difficulty of reconstructing the original lineation of the text, and my restlessness on this score is not diminished by Hart's reassurance that "generations of meticulous editorial scholarship" have verified the customary lineation. Customary lineation is customary; that is all. Chaos would result if each editor were to choose a different lineation. The fact is, the unique manuscript of Beowulf is written out as prose and contains lacunae (e.g., at 11. 240, 389-90, 403, 1803, and 2792). We do not know how many lines have been lost. I do not doubt that the poet, if he had wished, could have counted the number of lines he had composed up to a given moment, but I am not sure that our count would square with his.

Hart finds that the desire to unify a text by numerical proportionality was an "essential" component of the literary aesthetic of the Beowulf poet and his age. Clearly such a desire was an occasional component of the literary aesthetic of a few medieval authors, but I doubt that it was essential even among these, while most vernacular poets seem to have pursued their craft without recourse to numerical design. Egil Skallagrímsson's Hofuðlausn shows numerical patterning, but the patterning is elementary and the poem is short and stanzaic. Whoever wrote The Phoenix was a learned man. Half the poem paraphrases a Latin source, much of the rest reveals the author's familiarity with exegetical criticism, and in lines 547-48 the author tells us of his careful mode of composition ("ic . . leoð somnige, / write woðcræfte" 'I gather the materials for the song [from different sources], write it with poetic art'). I am perfectly willing to be convinced that he employed numerical design. If he did, we still know no more about the art of Beowulf, which is a poem of a different sort. 